\title{
Effect of the work environment on the communication of information in science
}

\author{
J.G. Smith \\ School of Librarianship, University of Cape Town, Private Bag, Rondebosch, 7700 Republic of South Africa \\ jgs@education.uct.ac.za
}

\begin{abstract}
The effect of the work environment on the communication of information in science is examined. The main characteristics that distinguish the communication of information in science and the conceptual issues that pertain to the process are circumscribed. The article is further based on data derived from an empirical study that investigated the communication of information among crystallographers in South Africa. The crystallographers conducted research in one of three work environments: universities, or research institutes, or $R \& D$ facilities in industry. The results strongly indicate that each work environment predicated distinct information communication behaviour patterns. Each group interacted differently with formal and informal communication systems, they used different channels of communication, they awarded different values to the role of conferences in the communication process, they used different methods to seek information to satisfy various information needs, and their research output varied. The clear differences in the demands of each work environment, the organizational structure and ethos of the employing institution, and the specific work activities that the crystallographers were engaged in, thus, all impacted on their information communication behaviour.
\end{abstract}

\begin{abstract}
Die invloed van die werkomgewing op die kommunikasie van inligting in die natuurwetenskappe word bestudeer. Die hoofeienskappe wat die kommunikasie van inligting in die natuurwetenskappe onderskei en konseptuele aspekte wat betrekking het op die proses, word omskryf. Die artikel is gebaseer op data verkry van 'n empiriese studie wat die kommunikasie van inligting onder kristallograwe in een van drie werkomgewings - universiteite, navorsingsinstansies en industrieë - in Suid-Afrika ondersoek het. Die resultate toon duidelik onderskeibare inligtingskommunikasiepatrone in elke werkomgewing: die wisselwerking tussen formele en informele kommunikasiestelsels verskil by elke groep; verskillende kommunikasiekanale word gebruik; verskillende waardes word toegeken aan die rol wat konferensies in die kommunikasieproses speel; verskillende metodes word gebruik om inligting te verkry; en hul navorsinguitsette verskil. Die verskille in die eise van elke werkomgewing, die verskillende organisatoriese strukture, die etos van elke indiensnemende instansie en die spesifieke werkaktiwiteit waarby die kristallograwe betrokke is, het dus alles ' $n$ impak gehad op hulle inligtingskommunikasiegedrag.
\end{abstract}

The purpose of this article is to examine the effect of the work environment on the communication of information among scientists and to establish whether certain work environments constrain the communication process and if others might stimulate it. The article is based on information the author acquired in the literature and from an empirical study of the communication of information among a defined group of scientists in South Africa. For this study the author adopted a triangulated research approach, incorporating both quantitative and qualitative research designs to investigate the crystallographic community in South Africa. Data was gathered by conducting focus-group interviews followed by personal in-depth interviews with all crystallographers that were listed under the South African entry in the World directory of crystallographers and who were active and in South Africa at the time of the study $(\mathrm{N}=80)$.

Crystallography, in its narrowest sense, is concerned with the geometric description of crystals, their internal arrangement, and their properties. The term is most often used to describe studies of crystalline solids (either single crystals or crystalline powders), but it may also be extended to include the study of the structure and arrangement of all substances (of atoms in all matter). Thus, crystals, powders, amorphous materials, surfaces, liquids, and gases are all studied by absorption, diffraction, and other scattering methods (Kerr, 1987:47; McKie \& McKie, 1986:3).

The concept 'science' refers to any systematic body of knowledge that has been accumulated on a subject, a particular branch of knowledge or study; and in its most general sense as 'the state of knowing'. The concept, however, is generally used in the literature and in ordinary conversation in a more restrictive sense with the implied meaning that it is the branch of study in which facts are observed and classified, and usually quantitative laws are formulated and verified; and which involves the application of mathematical reasoning and data to natural phenomena (South Africa's green paper on science and technology, 1996:108). In this sense it is concerned 'with humans' understanding of the real world about them - the inherent properties of space, matter, energy, and their interactions' (Sherwood \& Maynard, 1992:151).

It is an accepted fact that the development of science and its perpetuation is dependent on the body of knowledge that underlies all scientific endeavour. The communication and transfer of information is thus an essential component of scientific research and Garvey (1979: 126) in his well-known analysis of the communication of information in science has argued very strongly that "communication is the essence of science'. The aim of all scientists is to contribute to the body of knowledge in their field and their ability to contribute to the advancement of science depends to an extent upon the amount and quality of their interaction with fellow scientists (Blau, 1974:391). Several studies have, therefore, indicated that scientists spend a far larger proportion of their time on information communication activities than most other workers. Scientific research is essentially a corporate activity and a 
distinctive feature and accepted social norm of the scientific community is the concept of a 'communality' of ideas, that is a shared commodity that belongs to everyone (Kronick, 1988: 222). Science, furthermore, is cumulative and each scientist builds on previously recorded knowledge, on the work of colleagues and predecessors.

\section{Communication of information in science}

Studying the literature relating to scientific communication, Menzel (1966:1000-1003) came to the conclusion that five characteristics could be isolated which adequately conceptualize the process, namely:

- The acts involved in scientific communication constitute a system which include all the methods by means of which scientific messages are transmitted. Menzel therefore contends that scientists as generators and as users of information constitute interconnected publics.

- The effective transmission of a message to the recipient often involves many channels of communication acting synergistically.

- Informal, unplanned communication plays an important role in the science communication system and there appears to be a regularity in the pattern of unplanned communication.

- Scientists constitute publics who have a number of common interests and norms of behaviour which uniquely link them.

- Science information communication systems serve multiple functions that can be related to the scope and permanence with which the information needed by a particular scientist can be described in advance.

Garvey and Griffith (1968:129-130), in turn, have proposed that the following seven functions could serve as good indicators to circumscribe scientific communication:

- providing answers to specific questions;

- helping scientists stay abreast of new developments in a specific field;

- helping scientists acquire an understanding of a new field of research;

- identifying the major trends in a specific field and the relative importance of that field within its broader discipline;

- verifying the reliability of information by providing additional evidence;

- redirecting or broadening a scientist's interest field; and

- obtaining critical feedback to a scientist's own work.

Walker and Hurt (1990:xiv), further, suggest the encompassing function of providing a cumulative record of knowledge in a field as it exists at any given time. Such a record of knowledge serves a normative function, and it constitutes a reference point from which new theory is promulgated and to which new evidence may be added. However, recorded knowledge is never stable, it is dynamic and it adapts constantly to new inputs to the system of knowledge in a field.

In addition to this dependence on the formal structure of knowledge there is also strong reliance on informal commu- nication networks. The important role of informal communication of information in science has been highlighted by a number of researchers (cf. the seminal work of De Solla Price [1963] on 'invisible colleges', the series of investigations conducted by Garvey [1979] and others for the American Psychological Association [1963-1969], the research by Crane [1969; 1972], Crawford [1971], Allen [1977], Lacy \& Busch [1983], Pinelli et al. [1989]). Cronin (1982:229) has stated that informal communication did not evolve as a reaction to the short comings of the formal systems of communication but as a device created by scientists for scientists to serve a particular set of functions. The popularity of interpersonal communication lies in the interactive nature of the exchange process and the stimulation that collegiate interaction provides (Poland, 1991:62). It further promotes the simultaneous satisfaction of a number of information needs at a single encounter, for example a scientist when interacting with a colleague could obtain feedback on his/her research, be kept up-to-date on new developments he/she is unaware of, and further also derive stimulation from the interaction (Von Seggern, 1995:99).

There is growing evidence that information technology is impacting on the communication process and changing the way in which scientists communicate information about their work, both to their peers and to the public in general. In the past, the journal held a pivotal role in scientific communication and this was largely based on its embedded peer evaluation system that ensured minimum standards and further that it provided a reputable vehicle for laying claim to discoveries. More and more scientists are now using electronic media to communicate their research findings with the result that their work is not being evaluated and judged by the peer review system (Crawford \& Stucki, 1990:227).

\section{Factors that affect the communication of inform- ation}

A fundamental prerequisite to understanding the communication of information among scientists would be to examine the variables that affect the communication process and information-seeking behaviour. A wide diversity of factors have been listed in the literature and Paisley (1968:2) has suggested that

'the full array of information sources that are available; the uses to which information will be put; the background, motivation, professional orientation and other individual characteristics of the user; the social, political, economic and other systems that powerfully affect the user and his work; and the consequences of information use - e.g. productivity' might affect information communication behaviour.

Wilson (1981:6), in turn, suggests that a person's 'life world' which he defines as 'the totality of experiences centred upon the individual as an information user' underlies all information need that motivates and drives the communication process. Sub-worlds that have the greatest impact are the person's work environment, within which we 
find various reference groups with whom the user identifies such as fellow professionals and peer groups in the organization.

The author thus suggests that the variables that impact on scientists' information communication behaviour are an intermeshed combination of factors that range from their basic human needs (cf. Maslow's hierarchy), their innate personality traits (both affective and cognitive domains), cognitive and social aspects of information use, to external environmental factors which include: the scientists' interpersonal relationships, their demographic characteristics, factors related to their work situation and employing organization, their adherence to a discipline, the profession they belong to, exposure to information systems, both formal and informal, and the effects of the wider socio-economic and political environment.

\section{Work environment}

A number of studies have shown that scientists' immediate work environment has an important effect on their information communication behaviour. The work environment generally comprises of a number of hierarchically related sub-systems and the influence of each sub-system on information communication behaviour may range from the direct and immediate impact of the specific work-team with whom a person narrowly associates to the overall employing organization. Within any organization it has been found that various organizational factors impact on the flow of information within, to and from the organization and various status levels, work roles, specific activities, responsibilities, structures and policies tend to influence employees interaction with information and information communication behaviour.

Wilson (1984:200) is of the opinion that the various world views and distinctive cognitive styles of different occupations generate divergent information needs and demands which in turn affect information communication behaviour. He cites the example of persons working in bureaucracies who are generally absorbed with a sense of orderliness and concern for the legal basis of their establishment. This, in turn, results in an information-seeking behaviour that tends to be utilitarian, introverted, constrained and overly preoccupied with their own organization (Wilson, 1984:202).

Hall (1981:106), in turn, distinguishes between 'public use (of information) versus proprietary use versus the academic urge to know' as a means of differentiating between the communication and use of information in various work environments. He suggests that communication of information in the public domain (usually government institutions) is categorized by a tendency to seek information only when a crisis arises, to seek information that denotes consensus opinion, to use information to control situations, to acquire information to achieve pre-stated goals, and to collect everything as widely as possible. These users infrequently process the information they acquire to produce new information. Proprietary use of information (usually in industry or business) may be distinguished by pre-emptive actions to acquire in- formation that might be useful in future. Proprietary users set new targets constantly, and they retain only selected, prioritized information. Novel information is primarily used in their efforts to beat competitors and the emphasis is on the processing of information to produce unique marketable products. Only the most essential and critical internal reports are produced at as low a cost as possible. Academic communication of information is distinguished by an inherent 'urge to know' and the need to research the chronological development of a topic. Academics are particularly interested in theory, there is constant informal exchange of information through the medium of invisible colleges, and all information on a specific subject is collected. Information is highly processed by academic users and the objective of information use is to produce and publish new information, to achieve peer group approval and to claim priority rights for new ideas.

There is a whole body of research dealing with the interaction between organizational factors, information flow and performance (or productivity). Allen (1977) and his colleagues undertook expansive research into the flow of information in industrial organizations while Pelz (1967) and a number of co-workers extensively studied scientists conducting research in a number of diverse organizations. From these studies it would appear that organizational structures and 'climate' can have an important influence on users' information-seeking behaviour. The more open and transparent the structure and the more freedom granted and self-directed, or autonomous the employee is, the more effective and productive they are with an attendant increase in a need for and use of information. This further results in increased communication with colleagues within and without the organization, a general decrease in isolation and an increase in stimulation and increased information communication activities.

It has been demonstrated that in general information flows more freely in an academic and research environment than in industrial and government organizations. The latter type of organizations tend to inhibit the free interaction of information as they are often organized along bureaucratic lines and competition in industry as well as the tendency to secrecy in certain government agencies frequently results in access to information being restricted. Academics and research scientists, as a result of their less structured organizations and less restrictive work ethos, have fewer impediments to obstruct them when communicating and using information within and beyond the bounds of their organization. Their information communication system is based on unrestricted access to information, and the free and open communication of information. A distinguishing feature is the utilization of invisible colleges to promote the informal exchange of information and peer recognition (cf. Allen, 1977; Charton, 1992; Hanson, 1964; Pinelli et al., 1993; Slater \& Fisher, 1969).

Further characteristics of academic and research institutions that have been identified which could influence the communication of information and information-seeking behaviour of scientists attached to these institutions are the fair 
amount of autonomy afforded academics and researchers. They can generally pursue their own research interests and seek a result for its own ends. The prevailing ethos supports the urge to discover and explain nature and to search for theories and principles. However, there is considerable pressure to publish extensively and to utilize only specific reputable publication vehicles. There is a general requirement that advanced academic qualifications be pursued. They are engaged in diverse activities in disparate areas of specialization and levels of complexity which range from teaching (at both the under- and post-graduate levels), to research, to literary and other activities (Goodman, 1974:7-8; Stevenson, 1980:78-79).

The profit motivation and organizational structures in industry generally impose considerable restrictions on researches attached to the R\&D divisions of such organizations. Research is conducted only on problems which are of interest to the organization, and they are engaged in research to develop products that are market oriented. They work within tight time constraints, they are required to follow deadlines and fairly rigid schedules and there is a general concern with cost-effectiveness. Researchers in industry seek to develop and make things and use information for this purpose. They invent things and are engaged in solving problems within a practical operational situation. Thus new and original knowledge is rarely required. The reward system is based on materialistic gain and serves as inducement to continue to contribute in some way to technical knowledge and innovation. The value of knowledge in $R \& D$ research is related to its value as a commodity. Strong impediments thus operate to prevent open access to information and the free exchange of information outside the immediate work environment. Research results may not be freely publicized and have to be contained within the organization and not communicated to the profession at large. The social system is thus characterized by restrictions, security classification, and proprietary claims to knowledge (Pinelli, 1991:12-13). These constraints restrict the free flow of information and inhibit the formation in industry, 'of anything resembling an invisible college' (Allen, 1977:41).

\section{Work environment and crystallographers in South Africa}

As mentioned above, an empirical study was conducted to investigate the communication of information among crystallographers in South Africa and the entire crystallographic population that was active at the time of the study was interviewed. The variables that were investigated in the study were derived from a conceptual model of the information communication process that the author developed (Smith, 1991:92-93). The effect of work environment on information communication behaviour was one of the independent variables that was investigated in the study. The 80 crystallographers that were studied conducted research in one of three work environments, namely: universities, research institutes and industry. Altogether 49 crystallographers worked at one of 11 academic institutions, 18 worked at one of three research institutes and 13 worked at one of five R\&D facilities in industry.

The respondents' information communication behaviour was examined by questioning them on their interaction with both the formal and informal communication process, their interaction with various channels of communication, the role of conferences in the communication process, information seeking to satisfy various information needs, their level of professional involvement, and their research output. An interview schedule served as a framework for the interviews, and included a mix of question formats. Most questions were formatted as open-ended questions, but unstructured nondirective questions, as well as closed-ended questions, rating scales and inventories were incorporated as measuring instruments. This section of the article reports on a comparison of the results obtained for each of the three work environments.

\section{Role of formal information systems in the communi- cation process}

An individual scientist will generally interact with a variety of information systems, ranging from a number of formal systems either related to his/her work environment or social structure to the informal communication networks that she/he may be linked to. Studies have indicated that there is a clear interaction between an individual's information communication behaviour and the information systems that provide access to information. For example, the mere existence of a convenient and well-organized collection of information sources and formal information services may stimulate communication activities that would otherwise not have occurred. Conscious and unconscious needs for information may be activated by efficient facilities to meet them, while inadequate facilities tend to stifle information needs and communication behaviour. It is suggested that information users' perceptions of the information system serving them could be one of the primary determinants of successful or unsuccessful communication acts.

The crystallographers were asked to indicate how frequently they used their libraries, how they rated the service provided by their libraries, and also to attribute a value to the role of libraries in the communication process. A three-point rating scale was applied and the aggregated ratings for value, use and service, according to the three work environments, is presented in Table 1. The crystallographers in industry attributed the most value to their libraries' role in the communication process, and they further also rated the service given by their libraries the highest of all the work categories. In contrast to these ratings, they used their libraries the least frequently of all the work categories. Further probing during the interviews brought to light that a very harmonious relationship existed between these respondents and the information facilities that served them and although their libraries were usually situated within the $R \& D$ divisions, these respondents (particularly the more senior ones) rarely 
Table 1 Value attributed, use made and service rating of libraries according to work environment

\begin{tabular}{lcccc}
\hline \multicolumn{5}{c}{ Work environment } \\
\hline Rated aggregate & Industry & $\begin{array}{c}\text { Research } \\
\text { institutes }\end{array}$ & Universities & Total \\
\hline Library value & 4.85 & 3.44 & 3.33 & 3.60 \\
Library use & 1.92 & 2.22 & 3.43 & 2.91 \\
Library service & 4.54 & 3.33 & 1.08 & 2.15 \\
\hline
\end{tabular}

had to personally visit the libraries. All searching was done for them by the library staff, very effective current awareness services were provided and the actual information and documents that were retrieved were dispatched to the relevant users. The libraries in industry thus fulfilled an important function and were appreciated for the pro-active, value-added and user-oriented service that they provided.

The respondents in the research institutes used their libraries the second most frequently. They also valued their libraries as well as rated the service provided by their libraries the second most favourably of the three work categories. Once again it was evident during the interviews that these respondents received a value-added and very pro-active service from their libraries. The university respondents were the most active users of their libraries. They further valued the role of libraries in the communication process only slightly less than the research institute respondents, but they rated the service received far lower than the other categories of respondents. It transpired during the interviews that they were very dependent on the library to obtain the information they required for their various work activities and, because the university respondents received the least user-oriented library service of all the work categories, they were obliged to make extensive personal use of their libraries to acquire the information sources they required.

It would appear from the previous paragraphs that the more user-oriented and value-added a service the library offered, the more it was appreciated and less the need arose to visit it personally. However, it was acknowledged that personal, random browsing in the library was a valuable adjunct to information seeking and the communication process and this could be severely neglected if the need to visit the library is removed, for whatever reason.

Formal channels from which information was most frequently obtained

The respondents were requested to indicate in which formal information communication channels they mostly found the information they required and to rank the channels they used in order of importance (a 5 point rating scale, from $0=$ no value to $5=$ very valuable, was applied). The aggregated values for the formal communication channels used by each work environment is depicted in Figure 1.

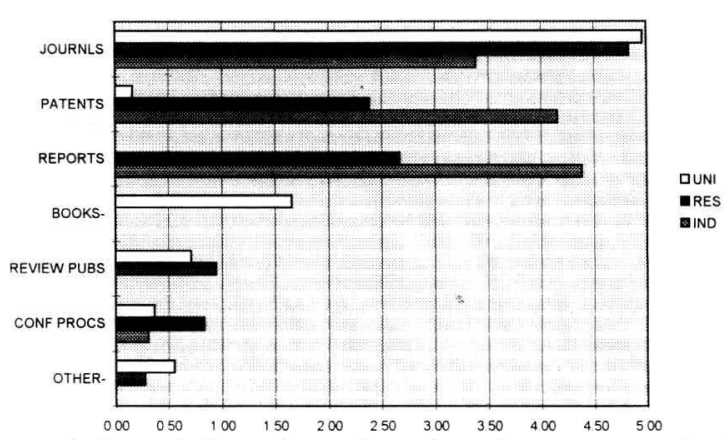

Figure 1 Formal channels used: work environment (rated values)

If all the crystallographers are considered it was clear that by far the most important and heavily used channel was journals. Patent specifications and technical reports were ranked in the second place followed by published monographs (books) in the third place. They were followed by review publications and conference proceedings and the final category of 'other' (ranked last) referred to information sources such as trade literature and the crystallographic database.

The respondents in industry only used four categories of formal communication channels, of which technical reports, closely followed by patent specifications were the most important and ranked considerably higher than the population aggregate. The journal literature was the third most used and rated channel. Conference proceedings, the fourth channel used by them, was ranked considerably lower than the other three categories. The respondents in research institutes used a wider range of channels (all except monographs) of which they ranked the journal literature first, followed by technical reports and patent specifications in the second and third positions. Although they also used review publications, conference proceedings and other material, they valued these channels considerably lower than the first three mentioned. The university respondents also used six of the seven channel categories (they did not use technical reports). They rated journals significantly higher than any other channel that they used. Books were rated much lower and review publications, other material, conference proceedings, and patents (in ranked order) received even lower ratings.

In conclusion it can be stated that journals were rated far higher than the other channels by the university and research institute respondents, while the industry respondents attributed a higher value to technical reports and patents. The latter two categories were also highly rated (second and third place) by the research institute respondents. The only subcategory to use books were the university respondents, while review publications were used only by those respondents in universities and the research institutes. Conference proceedings were used by all categories, but not rated very highly.

Many of these findings are in accordance with results from a number of other studies which have reported that journals are the most frequently used and valued information channel in science, and while monographs are important, they are not as critical as the journal literature (cf. Charton, 1992; Mick et 
al., 1980; Skelton, 1973). According to Allen (1977:73) applied scientists in industry infrequently use the scholarly professional journals in their field. The nature of their work often affects the source of information used, for example professionally orientated work usually results in the consultation of sources outside the organization, while work that is operational in focus results in the use of internally generated and available sources. A further factor is that they interact more readily with information sources closely attuned to their work environment and publications that contain specific answers in a familiar and digestible format. (Pinelli, 1991). This would explain why the unpublished report 'is the principal written vehicle for transferring information in technology' (Allen, 1977:87).

\section{Informal communication of information}

Many studies that have investigated the use of communication channels have concentrated predominantly on formal channels of communication, often totally neglecting the very important aspect of the informal communication of information. Brittain (1982:145) has estimated that informal communication of information takes up a considerable proportion (between $50 \%$ to $80 \%$ ) of all communications of researchers and academics and that outside the research and academic environment this ratio could be even higher as

'the work of practitioners revolves around clients,

local information, local gossip and hearsay, as well

as the more traditional informal communications

such as conferences and meetings'.

Research conducted by Allen (1977) and colleagues has indicated that the most frequently exploited channel of communication among applied scientists in industry is direct oral communication.

To establish the role of informal communication among the members of the South African crystallographic community, the respondents were questioned on the informal contacts that they maintained with respect to their research and/or work situation. They were requested to provide the names of all the persons (and their affiliation) with whom they exchanged information on a regular basis within and without South Africa. From this data contacts to crystallographers listed in the World directory of crystallographers were identified and a distinction was drawn between South African and foreign contacts. It was further possible to establish which of the respondents received contacts from other respondents and the number of contacts received. The average number of contacts in the various categories that the respondents in the three work environments were maintaining is represented in Table 2.

It is clear that the respondents in industry and at the research institutes were more active in initiating and maintaining interpersonal communication links than their counterparts at universities. The highest average total number of contacts, total foreign contacts, and contacts to South African crystallographers was made by the respondents in industry while the respondents at research institutes were a close
Table 2 Contacts made and received: work environment

\begin{tabular}{lcccc}
\hline \multicolumn{5}{c}{ Work environment } \\
\hline Averages & Industry & $\begin{array}{c}\text { Research } \\
\text { institutes }\end{array}$ & Universities & Total \\
\hline SACON & 4.77 & 4.78 & 3.35 & 3.90 \\
SACRYC & 3.54 & 2.94 & 2.06 & 2.50 \\
FCON & 3.62 & 3.22 & 2.41 & 2.79 \\
FCRYC & 0.92 & 1.56 & 1.31 & 1.30 \\
TCON & 8.38 & 8.00 & 5.76 & 6.69 \\
TCRYC & 4.46 & 4.50 & 3.37 & 3.80 \\
CONREC & 1.38 & 2.17 & 2.88 & 2.48 \\
\hline
\end{tabular}

Key: SACON - all contacts made in South Africa; SACRYC - contacts with South African crystallographers; FCON - contacts with all foreigners; FCRYC - contacts with foreign crystallographers; TCON - all contacts; TCRYC - all contacts with crystallographers; CONREC contacts received.

second. The most contacts to persons in general in South Africa, to foreign crystallographers, and to crystallographers in total, were made by the respondents at research institutes, and in all but one of these instances the respondents in industry made the second most contacts. The only instance where the respondent at universities maintained more contacts than the population average was when they contacted foreign crystallographers and then their number of contacts ranked second to the research institute respondents. However, it is abundantly clear from Table 2 that the university respondents received the most contacts, followed by the research institute respondents.

The data was further analysed to establish the work environments of the persons with whom the respondents regularly communicated in South Africa. This data has been graphically depicted in Figure 2 - by far the most communication took place between the respondents and persons conducting research at universities (64\% of the instances). The other interpersonal communication took place with persons conducting research at research institutes $(16 \%$ of the instances), persons conducting research in industry ( $11 \%$ of the instances), and other categories (9\% of the instances) which mostly consisted of clients and suppliers of equipment.

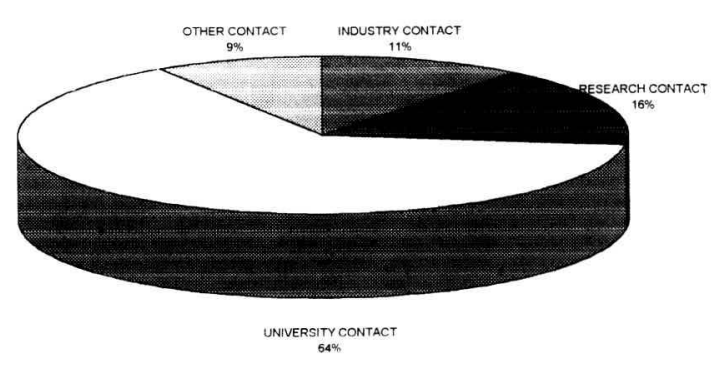

Figure 2 Work environments of the persons contacted 
The data was further analysed to establish to what extent respondents from specific work environments communicated outside their own work environments. This data is represented in Table 3. The overwhelming majority of respondents maintained contacts with persons at universities and, other than the university respondents, this meant that informal communication links were generally forged with persons outside their own work environments. It would strongly suggest that the respondents in industry and the research institutes rely heavily on their colleagues at universities to provide the information they require to satisfy a variety of information needs.

\section{Information seeking to satisfy the need to keep up-to- date}

It is a fundamental requirement that any person permanently engaged in research should keep up-to-date with the latest information being generated in his/her field of endeavour. This need to stay abreast with the latest research and information output is, furthermore, one of the important incentives that sets the communication process in motion. Each respondent was, therefore, requested during the interviews to indicate how they kept up-to-date and further to rate each

Table 3 Communication between respondents by work environment

\begin{tabular}{lcccc}
\hline \multicolumn{5}{c}{ Work environment } \\
\hline 96 contact & Industry & $\begin{array}{c}\text { Reseach } \\
\text { institutes }\end{array}$ & Universities & Total \\
\hline Industry contact & $11 \%$ & $13 \%$ & $10 \%$ & $11 \%$ \\
Research contact & $24 \%$ & $12 \%$ & $16 \%$ & $16 \%$ \\
University contact & $58 \%$ & $55 \%$ & $71 \%$ & $64 \%$ \\
Other contact & $6 \%$ & $21 \%$ & $4 \%$ & $9 \%$ \\
Total contact & $100 \%$ & $100 \%$ & $100 \%$ & $100 \%$ \\
\hline
\end{tabular}

Table 4 Current awareness methods: ranked values: work environment

\begin{tabular}{lcccc}
\hline \multicolumn{5}{c}{ Work environment } \\
\hline Ranked value & Industry & $\begin{array}{l}\text { Research } \\
\text { institutes }\end{array}$ & Universities & Total \\
\hline Cont PGS CIRC & 1.54 & 0.89 & 0.06 & 0.49 \\
CA bulletins & 1.15 & 1.28 & 0.08 & 0.53 \\
Other CA & 0.23 & 0.89 & 1.10 & 0.91 \\
COLLS Commun & 0.92 & 0.67 & 1.49 & 1.21 \\
Conferences & 0.92 & 1.39 & 1.33 & 1.28 \\
SDI CA & 2.62 & 2.44 & 0.54 & 1.32 \\
CA publications & 0.00 & 1.78 & 1.73 & 1.46 \\
Journals scan & 2.92 & 2.11 & 3.65 & 3.19 \\
\hline
\end{tabular}

method on a scale of 1-5 to denote the value of each method. The aggregated ranked values for each work environment's current awareness methods are outlined in Table 4.

The current awareness method that the respondents in industry valued most was to regularly scan new journal issues that were usually circulated to them by their library. The second most valued method was to obtain output from selective dissemination of information (SDI) services provided by, or subscribed to, by their libraries. The next most valued method was to scan contents pages reproduced and circulated by the library, followed by the regular perusing of current awareness bulletins produced by their libraries. Communication with colleagues and attending conferences were both rated fifth and other methods (which included scanning information produced by suppliers, new reports and patent specifications) were rated sixth by them.

Respondents from the research institute environment attributed the most value to obtaining SDI output and then secondly to scanning new journals that were either circulated to them or which were housed in the library. Their third most valued method was to scan current awareness publications the library subscribed to, followed by conference attendance and the scanning of current awareness bulletins produced by their libraries in the fourth and fifth place. Scanning contents pages circulated by their libraries, and 'other' methods were rated sixth, while communicating with colleagues was rated seventh.

The academic respondents attributed by far the most importance to journal scanning as a method of keeping up-todate. This was followed by scanning current awareness publications, communication with colleagues, and attending conferences in the second to fourth places. Other methods (which included the use of students and 'gatekeepers') featured fifth. The least valued methods were SDI services, the scanning of current awareness bulletins and content pages circulated by their libraries. The reason for this could be attributed to the fact that not many university libraries provided such services.

\section{Information seeking to satisfy a need for exhaustive information}

Most researchers, before embarking on a new research project, will first establish the state-of-the-art of the new field. This avoids unnecessary duplication, provides methodological insight and usually helps to clarify the researcher's thought process. To discover how the crystallographers satisfied such an exhaustive need for information before engaging in new research, they were asked to indicate how they went about the process, which information communication channels they used and the usefulness rating of each channel (on a scale of $1-5$, from little use to very useful).

The data analysed according to work environment is depicted in Table 5. By far the most valued method used by the respondents in industry was to approach their library to conduct a literature search on their behalf. The second most valued method was to search in their library's database for 
information held in their library. The reason given by the industry respondents for the high rating for this method was that it provided access to all the technical reports and patent specifications held by the library, an invaluable source of information for them. They then rated contacts with experts in the field for information, and other methods (which included searching the world's patent literature and their own knowledge and work) in the third and fourth place. Contacting colleagues, conducting their own online, CD-ROM or manual searches, and random unstructured searching were rarely used.

Although the respondents in research institutes also used their library to conduct literature searches and valued this method the most, they were less reliant on this method than their counterparts in industry. They thus attributed higher values to a wider range of methods. Their second most important method was to search their library's internal databases (once again for the report and patent literature held by their libraries), closely followed by their own manual literature searches, contacting experts in the field and conducting their own online searches in the third to fifth positions. They infrequently contacted colleagues and rarely searched randomly.

The respondents at universities utilized four methods fairly extensively. Once again the most valued method was to request their libraries to conduct a literature search for them. This was followed by their own manual literature search, searching their own and other literature randomly and other methods (which included searching the Cambridge crystallographic database and following up citations in publications they had previously read) in the second to fourth positions. This sub-group infrequently contacted colleagues or experts, rarely conducted their own CD-ROM and other online searches, and never searched their own library's internal databases when conducting an exhaustive literature search before embarking on a new project.

A surprising outcome was that the university respondents rated unsystematic, random searching so highly and that they

Table 5 Information seeking for new research: work environment - ranked values

\begin{tabular}{lcccc}
\hline \multicolumn{5}{c}{ Work environment } \\
\hline Ranked value & $\begin{array}{c}\text { Research } \\
\text { Industry }\end{array}$ & institute & Universities & Total \\
\hline Contact colleagues & 0.77 & 0.50 & 0.69 & 0.66 \\
Own online search & 0.62 & 1.61 & 0.51 & 0.78 \\
Contact experts & 1.38 & 1.89 & 0.41 & 0.90 \\
Library database searched & 2.62 & 2.50 & 0.00 & 0.99 \\
Other methods & 1.08 & 0.00 & 1.61 & 1.16 \\
Own random search & 0.38 & 0.17 & 2.04 & 1.35 \\
Own manual search & 0.62 & 2.00 & 2.59 & 2.14 \\
Library searches & 4.54 & 3.06 & 3.12 & 3.34 \\
\hline
\end{tabular}

and the respondents at research institutes preferred conducting their own manual searches to using electronic media. Further probing elicited that the serendipity factor in random searching is important and secondly that not many of the databases that the crystallographers required were available in their libraries in CD-ROM format. They thus preferred to delegate online searching in remote databases (such as DIALOG searches) to information professionals and to manually search such sources as Chemical abstracts.

\section{Information seeking to find information to solve a work- related problem}

The third main need category that gives rise to information gathering is when the researcher encounters a problem in the work situation. To establish the information seeking behaviour patterns that related to this category of need, the respondents were asked to indicate how they found information to resolve their work-related problems, the communication channels they used and the usefulness of each of the channels they used (a rating scale of 1 [not useful] to 5 [very useful] was applied). The aggregated rated values for each work environment is outlined in Figure 3.

The respondents in industry first approached their colleagues in the work-place, then local experts and then overseas experts to solve their problems. Searching the literature was used far less frequently and not rated very highly. Respondents in the research institute environment, in turn, rated approaching local experts (1st place) and experts abroad ( 2 nd place) higher than their colleagues as sources of information when they had a work-related problem. The literature, although more highly rated than in the industry environment, was the least valued and least frequently used method to obtain information to solve a problem.

The respondents in universities first approached their colleagues and then local experts when they encountered a problem and they rated the information obtained from these two sources in that order. This sub-category awarded the highest value of all the work environments to information obtained from the literature in a problem-solving situation. This method was rated third and preferred and used more frequently than consultation with experts from abroad (4th place rating). This sub-category also produced the three respondents who relied solely on their own knowledge to solve

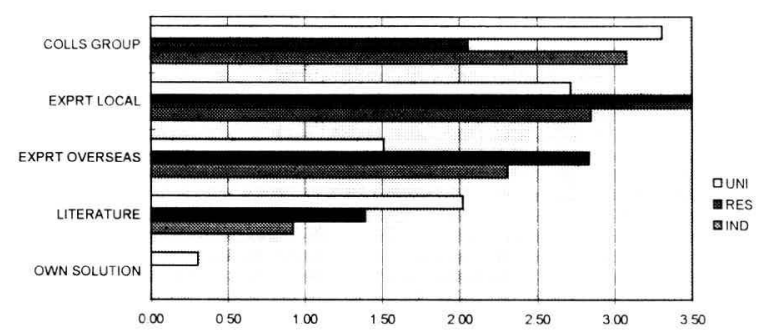

Figure 3 Information gathering to solve a problem: work environment - ranked values 
a problem and who stated that they never had the need to go beyond their own knowledge resources.

\section{Role of conferences in the communication process}

Conferences have ever since their inception in the seventeenth century (Walker \& Hurt, 1990:7) been highly esteemed for the role that they play in not only providing a forum to transfer current state-of-the-art information, but also for facilitating the informal transfer of information by means of the collegiate process. Conferences, thus, can play an important role to promote scientific and technological advance by providing a vehicle to introduce new ideas, to debate topics of current interest, and to stimulating the exchange of ideas, information and opinions amongst attendants (Smith, 1993:72).

To establish the role that conferences played in the information communication process, the crystallographers were asked to attribute a value (on a three point rating scale) to conferences as a mechanism in the process. They were further requested to indicate the reason why they attended conferences and to rate the reasons they had given (a scale from 0 , no importance, to 3 , very important was applied). The responses are depicted in Tables $6 \mathrm{a}$ and $6 \mathrm{~b}$.

Although the respondents in industry do attend conferences and they do deliver the odd paper, the general consensus of this group was that conferences do not play the same role in industry as they do in a research institute and/or academic environment. The respondents in industry indicated that they were more interested in new products and processes than in papers that covered theoretical issues and basic research. They thus rather attend trade fairs that have direct relevance

Table 6a Value of conferences in the communication process: work environment

\begin{tabular}{lcccc}
\hline Value (\% rating) & Industry & $\begin{array}{l}\text { Research } \\
\text { institutes }\end{array}$ & Universities & Total \\
\hline Valuable & 15.38 & 72.22 & 81.36 & 72.50 \\
Occasionally valuable & 84.62 & 16.67 & 14.29 & 22.50 \\
No value & 0.00 & 11.11 & 4.08 & 5.00 \\
\hline Total & 100.00 & 100.00 & 100.00 & 100.00 \\
\hline
\end{tabular}

Table 6b Reasons for attending conferences: work environment

\begin{tabular}{lcccc}
\hline & \multicolumn{5}{c}{ Research } & \\
Averaged rated values & Industry & institutes & Universities & Total \\
\hline Officiating & 0.23 & 0.33 & 0.37 & 0.34 \\
Listen to papers & 0.69 & 1.39 & 1.51 & 1.35 \\
Present papers, etc. & 0.46 & 1.50 & 2.14 & 1.73 \\
Formal discussion & 1.46 & 1.72 & 1.90 & 1.79 \\
Informal discussion & 1.85 & 1.89 & 2.12 & 2.03 \\
Making contacts & 2.77 & 2.39 & 2.31 & 2.40 \\
\hline
\end{tabular}

to their work and which provide a better forum to make valuable contacts. They also stated that they import new ideas and theoretical innovation more effectively by maintaining close ties with academics at local universities.

The main reason why respondents in industry attended conferences was for the personal contacts that they made and maintained. This group awarded the highest rating to interpersonal contact of the three work environments. Further probing indicated that specialist conferences provided the ideal venue to meet all the persons involved in research in their field, both pure and applied, and were specifically useful to create links with academics in the field. In this way they established current research trends, obtained new information and heard of new developments. The second most important reason why the respondents from industry attended conferences was to exchange information, both informally and more formally during discussion sessions. The respondents in in dustry only occasionally derived benefit from listening to papers as they were generally not sufficiently relevant, applied and specialized (hence the preference for trade fairs). The confidentiality of their work further precluded this group from publicizing their research and they thus rarely presented papers or posters.

Conferences were highly valued by the research institute community for the opportunities they provided to import new ideas and to broaden their perspectives. Thus the main reason why they attended conferences was to establish and rekindle personal contacts, both locally and internationally, to foster interpersonal interaction and the exchange of information. It was specifically stated that direct face-to-face interaction results in far more effective communication than when impersonal modes of communication, such as correspondence or the telephone, are used.

Informal discussions during 'corridor' encounters were rated second and were closely followed by formal discussions during sessions as a reason for attending conferences. The fourth reason for attending conferences was to present papers and posters. The presentation of papers by this group has declined over the past few decades as the focus of their research has shifted from conducting only basic research to a mix of basic research and applied contract research with the attendant problems of confidentiality. A further effect has been that conferences are not always sufficiently oriented towards their more applied research needs. Although the respondents from research institutes attributed a higher rating to listening to papers than their counterparts in industry, they still only rated it in the fifth position as a reason for attending.

As a group, the respondents from universities derived the most benefit from attending conferences and valued them the most highly. A number of the academic respondents commented that conferences make an important contribution to the global communication process. This sub-group had more equally distributed and weighted reasons for attending conferences than their counterparts in research institutes and in industry. Once again the most heavily weighted reason for attending was to make new contacts and to rekindle old ones. 
They stated that they attend conferences to rub minds with top scientists at the forefront of research and to derive inspiration and obtain new perspectives from them. This enabled them to keep abreast with the latest developments taking place in the mainstream of research. International conferences were particularly valuable to counter isolation and they created the opportunity to interact with a greater number of people working in the same field than is ever possible in South Africa.

Conferences were specifically valued for the opportunity they provided to test their work at the cutting edge of science and their second most highly rated reason to attend was to communicate their research findings to a select audience of experts. By presenting a paper or a poster they receive immediate peer evaluation of and feedback on their research. The university respondents thus placed far greater emphasis and importance on presenting papers and/or posters than their counterparts in the other two environments. The next most valued reasons to attend were for the opportunity that conferences presented to engage in informal and formal discussions and also to listen to papers and attend poster presentations. As with the other two work environments, the university respondents placed a low premium on any officiating function that they had to fulfil as a reason for attending.

\section{Research output}

The research process reaches its peak with the encoding of the research findings (this occurs either as a formally published product or as an unpublished internal report), the patenting of an invention, the production of a physical entity, or the introduction of a new process. This final stage signals the transfer of the interaction with the communication system from information seeking to information generation and concludes the research project. Thus, the information communication process, both formal and informal, culminates when the information generated during the research process becomes public knowledge.

To be able to examine and investigate the research output and publication patterns of the crystallographic community, the respondents were requested to submit a list of their publications, or any other form of encoded research output and further to provide as much detail regarding their research output as possible. From the data presented in Table 7 it is clear that the research output of the crystallographers can be grouped as follows: formal publications such as journal articles, review articles and book chapters; technical reports that were produced within the organization; patents that were promulgated; and invited lecture or conference presentations. It was assumed that research that culminated in the production of a product or the generation of a process would be verbally encoded in the format of an internal report produced for the institution or company. Where the confidentiality of the research prevented the respondent from providing the required information, the researcher requested that the
Table 7 Channels used for research output: work environment

\begin{tabular}{lcccc}
\hline Output distribution \% & Industry & $\begin{array}{c}\text { Research } \\
\text { institutes }\end{array}$ & Universities & Total \\
\hline Publications & 9.38 & 23.28 & 70.56 & 49.98 \\
Conferences present. & 7.69 & 15.80 & 28.27 & 22.12 \\
Reports & 70.39 & 57.63 & 1.12 & 25.09 \\
Patents & 12.54 & 3.29 & 0.04 & 2.81 \\
\hline Total & 100.00 & 100.00 & 100.00 & 100.00 \\
\hline
\end{tabular}

average number of reports or patents completed each year be divulged.

In industry the encoded research output was very clearly technical reports $(70.39 \%$ of all channels used) with patents (12.54\%), publications $(9.38 \%)$ and conference presentations (7.69\%) lagging far behind. This confirms the statements made by respondents and findings reported in the literature that the primary objective of research in industry is to improve products, production procedures and techniques with technical reports being the main method of conveying this type of research output to the company at large. Although patents only constituted $12.54 \%$ of the total encoded research output in industry, this group was by far the most prolific producers of patents of all the work categories. Producing formal publications and presenting papers at conferences was perceived to be an ancillary by-product which brought in few rewards in the workplace and which was further often, due to the confidential nature of the research, disallowed.

The crystallographers at research institutes were mostly engaged in applied research of which a high percentage was on contract for various clients in industry. Much of their research was thus also highly confidential and could generally not be published, nor presented at conferences. This clarifies why the majority of their research output was encoded in the form of technical reports that were distributed both internally and to their clients $(57.63 \%)$. This was followed by formal publications (23.28\%), then conference presentations (15.8\%) and lastly patents $(3.29 \%)$ where the rights were generally signed over to their clients. This group's use of channels to present their research endeavours evinced a pattern midway between that of the academics and the respondents in industry.

In the university environment the research output was predominantly in the form of published literature $(70.56 \%)$, the majority of which was in the form of journal articles with a few review articles and contributions to monographs. This group made the most presentations at conferences of all the work environment categories $(28.27 \%$ of their research output). They rarely contributed technical reports $(1.12 \%)$ and virtually never produced patents $(0.04 \%)$. These findings clearly indicate that the culmination of research in an 
academic environment is reached with production of a publication.

The average annual output was calculated for each respondent and the aggregated figures for the various channels within the three work environments also calculated (Table 8). The research institute community, with a total output of 4.27 items per annum, was slightly more productive than the respondents at universities (output of 3.85 items per annum) and those in industry (output of 3.26 contributions per annum). The output rate by channel varied for each work environment. The research institute respondents produced the highest number of reports (average of 2.21) followed closely by the industry respondents (average of 2.07 ) while the university respondents produced a mere 0.04 reports per annum.

The university respondents, however, contributed the highest number of formal publications with an annual average of 2.59. The research institute respondents produced the second highest number of publications (average of 1.21) with the industry respondents only contributing an average of 0.38 publications per annum. The university respondents also contributed the most conference presentations (average of 1.22 per annum), while the research institute respondents presented an average of 0.68 papers and/or posters per annum and the industry respondents only contributed 0.33 conference presentations per annum. The industry respondents produced the most patents (average of 0.48 per annum) followed by the research institute respondents at 0.16 patents per annum. The two patents produced amongst all the university respondents averaged out at an annual score of 0.00 .

\section{Conclusion}

From the data presented above it is clear that the crystallographers in each work environment manifested distinctly different information communication behaviour patterns. This can be summarized as follows:

- The respondents in industry received value-added and user-oriented library services and it was clear that extensive use was made of these services and that they were highly valued. They rarely had the need to personally search for information in the library. These crystallographers mostly used technical reports and patents, that is channels of communication that contained information directly applicable to the applied and production-

Table 8 Annual research output: work environment

\begin{tabular}{lcccc}
\hline Averaged output & Industry & $\begin{array}{c}\text { Research } \\
\text { institutes }\end{array}$ & Universities & Total \\
\hline Reports & 2.07 & 2.21 & 0.04 & 0.86 \\
Patents & 0.48 & 0.16 & 0.00 & 0.12 \\
Publications & 0.38 & 1.21 & 2.59 & 1.92 \\
Conference pres. & 0.33 & 0.68 & 1.22 & 0.95 \\
Total output & 3.26 & 4.27 & 3.85 & 3.85 \\
\hline
\end{tabular}

orientated nature of their work and less frequently derived information from scholarly journals. The respondents in industry were the most active of the three work environments in maintaining and fostering interpersonal communication links. It is evident that these crystallographers rarely approached persons within industry or even the research institutes when they required information and that they interacted mostly with academics when they wished to obtain information. The industry crystallographers relied heavily on their libraries current awareness and other services to keep up-to-date and to obtain exhaustive information before embarking on a new project. When they encountered a problem they approached colleagues or outside experts for information and rarely used the literature for this purpose. The industry respondents valued conference attendance the least of all the categories as they contended that conferences are not sufficiently tailored to their practical needs. The industry respondents research output was mostly encoded in the form of technical reports.

- The respondents in universities received the least useroriented library services and were thus obliged to personally search for information in their libraries. Although they used their libraries the most frequently of all the categories, they awarded the lowest rating for the services provided by their libraries. Academic respondents showed an overwhelming preference for scholarly journals and to a lesser extent for other formal publications as a source of information. They did not use technical reports and rarely used the patent literature. Although the respondents at universities made less interpersonal contacts than the other respondents, they received far more contacts than the other respondents. It is thus clear that the respondents from the other two work environments far more frequently approached their academic colleagues for information than what the academics approached the other environments for information. This would tend to confirm the argument that, in order to survive, a technology-based organization would have to constantly import new information and Allen further contends that technologists usually require human intervention to supplement and interpret the information contained in the published literature (Allen, 1988:3-18; 1977:3). The university respondents mostly kept up-to-date by personally monitoring the current journal literature and they were more prone to conducting their own literature searches than the other categories (although they also mostly requested the library to conduct literature searches on their behalf). The university crystallographers relied more on their colleagues at work and the literature than the other two groups when they encountered a work-related problem. The university respondents attributed the highest value to conferences of all the respondents and they not only valued conferences for the contacts that they make and inter-personal discussions, but also for the opportunity they provide to present their work to experts in the field. 
Publications were clearly by far the main research output of the academic crystallographers.

The crystallographers at the research institutes evinced communication behaviour patterns that fell somewhere between those of the academic and industry respondents. This could be attributed to the nature of their work as they conducted both basic research and applied research on contract for clients in industry. A further factor would be that although their institutes have similar organizational structures to academic institutions that encourages the free flow of information and independent research with few restrictions, they are also constrained by the movement towards contract research for industry which is highly regularized and very often confidential. Their interaction with their libraries were predicated by the services offered which were midway between the highly user-orientated services found in industry and the far more conservative approach found in universities. These respondents further used the widest range of formal communication channels of all the respondents (from scholarly journals to technical reports and patents). The research institute respondents were, like their industry counterparts, very active in initiating and maintaining inter-personal communication links (mostly with researchers at academic institutions). These respondents mostly kept up-to-date by means of the SDI service offered by their libraries and they also relied on their libraries to conduct literature searches for them. To solve work-related problems they mostly approached local experts and experts abroad. Conferences were valued more for the opportunities they offered for interpersonal interaction than for the opportunity to publicize their research. An interesting observation is that these respondents' research output was higher than that of the other two categories and they utilized a wider range of channels to present their completed research (mostly technical reports, but also journals, patents, and conference presentations).

It is thus clear that the fundamental differences between the social systems of researchers in industry, at universities and at research institutes, the difference in creative processes and creative products produced by these three categories of work environment, and their divergent work settings all contributed to the varying communication patterns that the crystallographers in each work environment manifested. The author, therefore, suggests that the demands of each work environment, the organizational structure and ethos of the employing institution, and the specific work activities that the crystallographers were engaged in all clearly impacted on their information communication behaviour.

\section{References}

ALLEN, T.J. 1977. Managing the flow of technology: technology transfer and the dissemination of technological information within the $R \& D$ organization. Cambridge, Mass.: MIT Press.
AMERICAN PSYCHOLOGICAL ASSOCIATION. 1963-1969.

Reports of the American Psychological Association's project on scientific information exchange in psychology. Vols. 1-3. Washington: A.P.A.

BLAU, J. 1974. Patterns of communication among high energy physicists. Sociometry, 37(3):391-406.

BRITTAIN, J. M. 1982. Pitfalls of user research and some neglected areas. Social science information studies, 2:139-148.

CHARTON, B. 1992. Chemists' use of libraries. Journal of chemical information and computer sciences, 32(3):199-203.

CRANE, D. 1969. Social structure in a group of scientists: a test of the 'invisible college' hypothesis. American sociological review, 34(3):335-352.

CRANE, D. 1972. Invisible colleges: diffusion of knowledge in scientific communities. Chicago: University of Chicago Press.

CRAWFORD, S. 1971. Informal communication among scientists in sleep research. Journal of the American Society for Information Science, 22(5):301-310.

CRAWFORD, S. \& STUCKI, L. 1990. Peer review and the changing research record. Journal of the American Society for Information Science, 41(3):223-228.

CRONIN, B. 1982. Invisible colleges and information transfer: a review and commentary with particular reference to the social sciences. Journal of documentation, 38(3):212-236.

GARVEY, W.D. 1979. Communication: the essence of science. Oxford: Pergamon.

GARVEY, W.D. \& GRIFFITH, B.C. 1968. Informal channels of communication in the behavioral sciences: their relevance in the structuring of formal bibliographic communication. In Montgomery, E.B. ed. Foundations of access to knowledge. Syracuse, NY: Syracuse University: 129-146.

GOODMAN, I. 1974. Information requirements of a university scientist. In Ayres, F.H. \& Hall, J.L. eds. Information services in university libraries. Bradford: SCONUL:6-16.

HALL, H. J. 1981. Patterns in the use of information: the right to be different. Journal of the American Society for Information Science, 32(2): 103-112.

HANSON, C.W. 1964. Research on users' needs: where is it getting us? Aslib proceedings, 16(2):64-78.

KERR, K.A. 1987. Crystallography. In Meyers, R.A. Encyclopedia of physical science and technology. New York: Academic Press: vol. 4:45-69.

KRONICK, D.A. 1988. Anonymity and identity: editorial policy in the early scientific journal. Library quarterly, 58(3):221-229.

LACY, W.B. \& BUSCH, L. 1983. Informal scientific communication in the agricultural sciences. Information processing \& management, 19(4):193-202.

MCKIE, D. \& MCKIE, C. 1986. Essentials of crystallography. Oxford: Blackwell Scientific Publications.

MICK C.K. et al. 1980. Towards usable user studies. Journal of the American Society for Information Science, 31(5):347-356.

MENZEL, H. 1966. Scientific communication: five items from social science research. American psychologist, 21(11):9991004.

PAISLEY, W.J. 1968. Information needs and uses. In Annual review of information science, 3. Chicago: William Benton: 1-30.

PELZ, D.C. 1967. Some social factors related to performance in a research organization. In Barber, B. \& Hirsch, W. eds. The sociology of science. New York: The Free Press:356-369.

PINELLI, T.E. 1991. The information-seeking habits and practices of engineers. Science and technology libraries, 11(3):5-25.

PINELLI, T.E. et al. 1989. Technical communications in aeronautics: results of an exploratory study. Washington, DC: National Aeronautics \& Space Administration, 4v. (NASA TM101534, TM-101625, TM-101626). 
PINELLI, T.E. et al. 1993. Information seeking behavior of engineers. In Kent, A. ed. Encyclopedia of library and information science; vol. 52. New York: Marcel Dekker:167200.

POLAND, J. 1991. Informal communication among scientists and engineers: a review of the literature. Science and technology libraries, 11(3):61-73.

PRICE, D.J. DE SOLLA. 1963. Little science, big science. New York: Columbia University Press.

SHERWOOD, R.S. \& MAYNARD, H.B. 1992. Technology. In McGraw-Hill encyclopedia of science and technology. 7th ed. New York: McGraw-Hill: vol. 18:151.

SKELTON, B. 1973. Scientists and social scientists as information users: a comparison of results of science user studies with the investigation into information requirements of the social sciences. Journal of librarianship, 15:138-156.

SLATER, M. \& FISHER, P. 1969. Use made of technical libraries. London: Aslib.

SMITH, J.G. 1991. Theoretical framework to study the communication of scientific information in a defined community. South African journal of library and information science, 59(2):84-94
SMITH, J.G. 1993. Role of conferences in the transfer of information. South African journal of library and information science, 61(2):68-74.

SOUTH AFRICA'S GREEN PAPER ON SCIENCE AND TECHNO$L O G Y$. 1996. Pretoria: Department of Arts, Culture, Science and Technology.

STEVENSON, M.B. 1980. Information and the academic community. Aslib proceedings, 32(2):78-81.

VON SEGGERN, M. 1995. Scientists, information seeking, and reference services. The reference librarian, 49/50:95-104.

WALKER, R.D. \& HURT, C.D. 1990. Scientific and technical literature: an introduction to forms of communication. Chicago: ALA.

WILSON, T.D. 1981. On user studies and information needs. Journal of documentation, 37(1):3-15.

WILSON, T.D. 1984. The cognitive approach to informationseeking behaviour and information seeking use. Social science information studies, 4(2/3):197-204.

WORLD DIRECTORY OF CRYSTALLOGRAPHERS AND OTHER SCIENTISTS EMPLOYING CRYSTALLOGRAPHIC METHODS. 1986. Dordrecht: D. Reidel for the International Union of Crystallography. 